\title{
nature
}

\section{Chernenko, Hart and Reagan}

\section{The first primaries in the US election campaign could yet help unlock the log-jam on arms control. President Reagan now has an incentive to move quickly for an agreement with the Soviet Union.}

WHAT possible connection can there be between what happened last week in Moscow and New Hampshire, the New England state which has so far outwitted rivals seeking to steal the distinction of being the first to hold primary election in presidential election year in the United States? In Moscow, Mr Konstantin Chernenko, the new Soviet leader, responded to President Reagan's earlier signals that an East-West accommodation would be welcome with a list of steps that might be taken on arms control. In New Hampshire, registered Democrats in what is traditionally and by temperament a Republican state surprised the pollsters (and perhaps even themselves) by voting for Senator Gary Hart as the Democratic Party's candidate for the presidential election in November. Their decision was echoed at the weekend by the Democrats of Maine. And the consequence of that, by a simple piece of political arithmetic, is that President Reagan will now have to respond positively to what Mr Chernenko had to say.

The calculation is straightforward. When, a month ago, $\mathrm{Mr}$ Reagan declared himself a candidate for a second term as president of the United States, his chief rival seemed to be $\mathrm{Mr}$ Walter Mondale, President Jimmy Carter's vice-president. Given the electoral advantages of an incumbent president, $\mathrm{Mr}$ Mondale must then have seemed a comfortable opponent. Hart's wins in New Hampshire and in Maine will have undermined that sense of security, if only by reminding the President and his advisers that in the coming election, as when President Carter was elected in 1976, the voters of the United States may decline to follow the agenda their party leaders have written for them. Whether or not Hart's campaign prospers, the choice of the Democratic candidate will now be postponed, perhaps until the convention planned at San Francisco in July, while the competition between Hart and Mondale, each of whom is committed to some version of a freeze on nuclear weapons, will increase the importance of arms control as an election issue. So, since there will not be much time between July and November and because Mr Chernenko is unlikely to want to help $\mathrm{Mr}$ Reagan to be re-elected, the administration in Washington has every reason to move quickly towards an accommodation.

\section{Tesi ban}

What can it do? The simplest but also the best immediate course is to take up Mr Chernenko's proposal that the threshold test-ban treaty, signed in 1974 , should promptly be ratified. The treaty requires that the signatories should not test nuclear weapons yielding more than 150 kilotons of TNT equivalent and also provides that, once the treaty has been ratified, each side will have to give the other details of its testing sites and their seismic characteristics and information about weapons tests carried out and that there should be at least two calibrating underground explosions at each testing site. Such data would help enormously to avoid uncertainties about remote verification of the kind that only a few weeks ago provoked the US Administration into accusations that the Soviet Union has been cheating. Indeed, the benefits of ratification are so obvious and immediate that it is hard to understand why the administration has not long since jumped upon them. Now, with the electoral wind blowing the way it is, both the administration and the Republican Senate would seem to have little choice.

Ratifying this single treaty will not, however, keep the electoral wolves from President Reagan's door nor seem to Mr Chernenko to be an adequate response to what he had to say last week. Ratifying the treaty, signed bilaterally in 1976, on the conduct of peaceful nuclear explosions would similarly fall short of what is required, especially now that even Soviet interest in this clumsy technique for making holes in the ground has diminished, but the agreement that on-site inspection should be allowed under the terms of the treaty should nevertheless be a useful precedent for the future. But as things have turned out, in New Hampshire and in Maine, what the President needs is an agreement that will seem to US electors to be a much more substantial constraint on the development of nuclear weapons.

There are only two fields in which there has been anything like enough preparation for an agreement to be within reach - the comprehensive test-ban agreement (within an ace of signature in 1980) and some extension of the Salt II agreement on strategic arms based on the past two years of negotiations at Geneva, now in suspended animation. The second is the better bet, for a comprehensive test-ban would require that the British Government should be involved (probably no great difficulty) and would in present circumstances be incomplete without the adherence of France and China (quite a different matter). So the US Administration has no choice but to put aside the scepticism of arms control agreements that has informed the past three years, to put forward the draft of a treaty on the reduction of strategic arms, to plead for a resumption of the Geneva talks (in April?) and to hope for an agreement before November.

If the administration feels coerced by events it should take comfort in the knowledge that some such step will in any case be needed by this time next year if the next review conference of the Non-Proliferation Treaty, due in August, is not to be yet another shouting match with the non-nuclear powers. Five years ago, the non-nuclear signatories of that treaty left the nuclear powers in no doubt that more substantial progress was required of them. On the present showing, they have nothing to report except that they have failed to agree on what should be done. Unless something can be said just over a year from now, the treaty may fall apart.

The administration's underlying difficulty, chiefly of its own making, is however more serious. The best part of four years in of fice seems to have persuaded the Reagan Administration of two awkward doctrines - that bilateral agreements with the Soviet Union on arms control are politically undesirable, militarily dangerous and probably unattainable on equitable terms, but that public support for the strategic doctrines by means of which the deployment of nuclear weapons has been legitimized has now melted away. This, it now emerges, is why the administration is pinning so much of its hopes on star wars, the ambition to make defences against hostile missiles so reliable that neither diplomatic agreements nor the deployment of strategic nuclear weapons would be necessary. The obvious snag is that the feasibility of star wars defences could not possibly be demonstrated for at least a decade, and is unlikely even then to satisfy legitimate military needs. Meanwhile, the United States, its allies and their opponents will somehow have to look to their security, of which arms control has become an indispensable component. President Reagan should have understood this from the beginning of his term of office, and may yet regret that he has had to wait for Mr Hart's early successes at the polls to drive the lesson home. 